\title{
Teachers' Perspectives of Difficulties Face Teaching English Language as a Foreign Language at the Intermediate Schools
}

\author{
Qusay Mahdi Mutar \\ University of Baghdad, Iraq
}

http://dx.doi.org/10.18415/ijmmu.v6i3.844

\begin{abstract}
The study attempts to determine the most influential difficulties that face Iraqi-English teachers as they have experienced through teaching process and the extent to which the variable of gender could influence teachers' perspectives toward the difficulties of teaching. A sample of (34) intermediate-school teachers were chosen randomly from different schools at Al-Karkh side of Baghdad city. A questionnaire of (37) items was administered to the study sample to collect the needed data. SPSS software version (20) was run to analyze the collected data. The findings of study revealed that there is no statistically significant difference between male and female teachers at the level $(\mathrm{a}=0.05)$ in their perspective toward the difficulties in teaching English. Additionally, the most influential difficulties encounter Iraqi-English teachers are the scarcity of equipment and facilities and difficulties with students. The study came out with a number of recommendations.
\end{abstract}

Keywords: Teachers' Perspectives; Difficulties; Teaching English Language

\section{Introduction}

In an era of globalization, English language has gained a critical position compared to the other international languages due to the ongoing advance in technology and other sciences, which take the English language as a medium in spreading their applications (Pakir, 1999). Thus, enormous efforts have been made to popularize English language in those countries that take English as a foreign or second language. Although the introduction of the English language as a mandatory subject in the curriculum of Iraqi schools on the initial stages onward, Teaching English has been diagnosed as a strenuous task for teachers in the Iraqi context in particular. The process of teaching and learning English as a foreign language unfortunately has not been able to live up the authorities' expectations.

As it is stated through literature, since the inclusion of English language course in the Iraqi curriculum, English teachers have continued in encountering a number of difficulties over teaching process such as the materials, language competence, the shortage of facilities, the inattentiveness of developing teacher profession, Teachers' relationships with each other. Additionally, Students effectiveness, the educational Supervision, and school curriculum, which have a significant impact on teacher's production of qualified students. Teaching language necessitates experiencing different approaches, methods, and teaching aids, which means that teachers need to consider more than one role in the classroom. Teachers have to focus on teaching lesson at the students' level of understanding, as well 
as, they have to cover the whole syllabus within the given time and assess students in the class (Archana, 2017).

Ornstein \& Hunking (2010) states that teacher is the most authoritative implementer of the curriculum. A teacher can be called as the main source of input for students. In addition, he claims that a teacher is the only one who can determine which aspects of the newly developed or ongoing curriculum necessary to be implemented or emphasized in a particular classroom according to his direct contact with students. Sakai \& Kikuchi (2009) point out that teachers have a very significant role in inspiring students in language learning. Thus, students are the direct beneficiary in identifying teachers' professional problems.

As aforementioned, teachers have a critical part in the learning process of English language and their attitudes toward classroom-related issues should be taken into consideration. Therefore, the focus of this study is on identifying the most influential difficulties faced by Iraqi EFL teachers. The result of the study will be useful for the decisions maker and English teachers to determine the impacting problems on teaching process consequently it helps to find appropriate solutions to improve the quality of teaching and learning of English at the intermediate level.

\subsection{Study Objective}

The purpose of the study is to determine the most influential difficulties that face Iraqi-English teachers from their perspectives and the extent to which the variable of gender could influence teachers' point of view toward the difficulties of teaching.

\subsection{Research Questions}

1- What are the most influential difficulties encountering Iraqi-English teachers as seen by the teachers themselves?

2- Does the variable of gender has a significant influence on teacher's perspectives toward teaching difficulties?

For hypothesis,

- There is no significant difference due to the gender of teachers at the $(\alpha=0.05)$ level in term of perspectives toward difficulties in teaching English.

\section{Literature Review}

\section{1 English Teacher's Role and Teaching Difficulties}

English has been presented as a means of communication with a new world. It is recognized more affordable compared to other languages. Getting grasp of the English language means to raise an ability to comprehend and communicate with others. This communication embeds in different forms; it could be an exchanging in ideas with foreigners who speak a variety of languages face to face or on social media, as well as Accessing the knowledge that is stocked in the world's libraries published in English (Crystal, 2003). So as to communicate properly, it is inevitable for learners to enhance their memories with an abundant of vocabularies and grammar structures. The process of learning is complex since it deals with learning a foreign language. Various factors could take part in learning English language such as time, context, teaching methods, type of learners, and difficulties that encounter teachers.

Brown (2007) believes that learning English language is not an easy task; it necessitates great efforts to be mastered. He also states that teaching is a process of showing or helping someone to learn how to do something, either by giving instructions or providing information to promote his knowledge over time (brown, 2014). Over teaching process, teacher's role in the classroom has an undeniable 
significance in which different types of functions in the classroom context necessitate his existence to be achieved. In fact, the whole idea of teaching revolves around teacher's control of picking up the general objectives from the curriculum; constituting a syllabus that covers completely the required topics. In addition to designing clear objectives for each lesson concern with students' needs and difficulties that may face them and how to overcome these difficulties along with maintaining students organization and comprehension for topics.

Harmer (2007) pointed out that teaching and learning are an integral part of each other; teacher acts as a facilitator by imparting information to the learner side smoothly and accurately, as well as giving enough space for the learner to work independently to foster his autonomy. Teachers' responsibility is not only about organizing, planning, and designing lessons to achieve the curriculum objectives but also to create a positive atmosphere inside the class give a kind of convenience for emerging new thoughts and ideas and inspire the learner to raise questions to enhance their knowledge (Lee \& Van Patten, 2003).

According to Sue (2013), Teacher could engage a number of major roles in classroom: Controller (teacher is fully responsible over class in term of students' behaviors, acts, and topic they go through. Prompter (creating a positive ambiance supporting all students with different personalities and learning preferences, as well as the teacher has to constitute an interpersonal relationship with students to accomplish the educational activities). Resource (a teacher should work as a resource available all the time to provide assistance and information for students when needed). Assessor (assessment regards as a significant means adopted by the teacher to reveal students' level of knowledge. Teachers should carefully consider the assessment technique to use in measuring learning outcomes). Organizer (a teacher's job as an organizer is an extremely noteworthy in dealing with a class. A teacher needs to design well progress of time in regards of taking care of the classes within the stipulated time; covering academic as well as interpersonal skills by counting on different techniques the give rise to practical approaches. Teacher's experience takes an important space in dealing with time inside the classroom that could achieve the purposeful targets of teaching and learning.

Facing difficulties over teaching process has attributed to many reasons such as the inattentiveness of developing teacher profession, the scarcity of Equipment and Facilities, teachers' relationship with each other, which differs from one to another based on the individual differences. Additionally, Students effectiveness, the educational Supervision, and school curriculum are significant domains since they have an effect on teachers' reactions toward the surrounding environment and increase the workload. All these domains will be discussed to reveal their importance.

\subsubsection{Developing Teacher Profession}

Professional development is a necessary demand for teachers. Moreover, experience enables teachers to attract students ' attention that makes them more effective in controlling the classroom. This may positively reflect on students ' performance and improve their methods of learning. Experienced teachers are different from those who still have a little experience in the teaching field in the term of skills, knowledge, and attitudes. Zwart et al (2012) underscore that teachers have to continue to evolve as they practicing the teaching profession. Similarly, Zeichner \& Noffke (2001) have emphasized the great significance of constant professional learning for teachers over all fields.

\subsubsection{Equipment and Facilities Scarcity}

Toolan (2009) states that a variety of teaching methods and aids could be adopted through the teaching process. Thus, teachers have to select the most appropriate and practical ones for what he teaches and the level of students' proficiency. In the education system, teaching aids can take a wide range in providing the learner with what they need to enhance their learning. However, the traditional use of certain methods without a direct effect on the teaching process has controlled most of the Arab communities, and the contemporary concept of teaching technique is lacking in regulatory technique (Hammadat, 2009). 


\subsubsection{Difficulties with Colleagues}

Acker (1999) points out the necessity to focus on teacher motivation, the interaction among teachers, and how to create a positive ambiance in which they can work together towards the common goal in improving students' competence. Teachers' professional relationships should abide by standards governing the ways teachers request and provide assistance. Zwart et al (2012) show that paired-teacher cooperation present advantageous rewards for the teaching process. It shows that when teachers observe each other and give feedback on the observed practice, a great number of improvements in classroom instruction are achieved. The study also shows that teachers learn the most when they have the chance to discuss their experiences in an atmosphere of trust, confidence, and constructiveness.

\subsubsection{Difficulties with Students}

Horne (2004) states for a healthy learning process, creating learning spaces regard as a significant step. Different studies have shown arguments about the extent to which teaching methods and learning spaces could effect on students' achievement. Whether these spaces are virtual or physical, the main goal is how to facilitate the learning process through impart the purposeful information to the receiver's ear. Here, the collaborative relations between teacher and learners help students to complete tasks, to solve a problem, and to raise up outcomes. Otherwise, adopting the traditional way of teaching keep teacher away from achieving what he had in mind (Wang et al, 2017).

\subsubsection{Difficulties in Educational Supervision}

As an important matter, "the educational supervision should be modified to be more conventional for teacher" that was English teachers' view (Mahmoud, 2003). He shows that English teachers expressed a strong desire for a type of supervisors that meet their needs in terms of mutual respect and trust, and cooperation. Ormstn (1995) uncovers that most teachers complaining of not being provided with feedbacks when supervisors visit their classes. Agnew (1999) points out that the supervisor must consider two things: the human side and the quality of education, in which, he needs to be skillful in making any judgment.

\subsubsection{Difficulties in School Text Book}

Only as good as the teacher who uses it is a textbook. Moreover, it is important to keep in mind that in your teaching area, a textbook is just one tool, which is a very important tool. Usually, teachers over-rely on textbooks and do not consider other materials for the classroom. In other times, some teachers reject to adopt learning approaches included in the textbook, either covers insufficiently topics or outdated. Khankar's (2001) attributed the difficulty of Textbook to the scarcity of content that interests students; Textbook does not consider the cultural matters, which enrich students' knowledge with national events; the content does not support the self-learning.

\subsection{Previous Studies}

This section touches upon some relevant studies that addressed difficulties encounter the English teachers through their profession. Mahmoud (2003) carried out a study to investigate the professional difficulties that face English teachers and how could these difficulties affect teachers' performance inside the classroom. The researcher considered a number of variables, such as gender, academic qualification, years of experience, and training courses to determine the difficulties. Total of (261) male and female teachers, served as the study sample, were chosen randomly from different secondary schools. As for collecting data, the researcher employed a five Likert scale questionnaire of (61) items, spread over (9) domains, was designed by Qadomi (1996). The findings have shown the majority of study sample experienced difficulties over all domains. In regard of teachers' gender, there was no statistically significant difference between male and female in domains (B, D, F, G, and H). Additionally, the results 
showed a significant correlation between teachers' performance inside the classroom and academic qualification, years of experience, and training courses.

Similarly, Evue (2013) conducted a study in which he probed Challenges facing the teaching of English language in secondary schools in Aniocha south local government area of Delta state Nigeria. To do this, a sample of (66) teachers were chosen from (15) secondary public schools in Delta state. As for study instruments to gather up the needed data, the researcher employed interviews and a questionnaire consisted of three sections was administered to the selected sample of teachers. Regarding the result, it showed the lack of teaching aids, shortage of using modern teaching resources, the absent of educational technology, using traditional method and tools, and inexperienced teachers all play a critical role to the teaching of English. To figure out how could secondary school English teachers efficacy affected by different challenges and problem, Aloysius (2015) chose randomly a sample of (82) secondary school teachers, where (20) teachers involved in a semi-structured interview to obtain in-depth information about teachers' perspectives, whereas (62) teacher participated in answering a questionnaire consisting of three sections. The results revealed a significant correlatFion between the levels of teaching efficacy of English teacher and variables, such as self-development, teaching resources, classroom problems, and teacher background.

In a similar vein, in (2015) Nada Rashid attempted to explore the factors that give rise to the weakness of teaching English as a foreign language, as well as the possible solutions to manage this problem. So as to achieve this objective, the researcher adopted the mixed method approach by using two instruments: open-ended interview and a questionnaire which was administered to a sample of (50) male and female teachers. The questionnaire consisted of three main sections with (25) items considered problems that teachers face over the teaching process, such as problems related to the experience of teachers, problems related to educational context, and teaching aids. The finding revealed there is a significant correlation between teaching process and teacher experience, teaching methods, size of class, number of students, and teaching aids.

Razmjoo \& Mavaddat (2016) used a mixed method approach to conduct a study exploring the professional challenges that encounter English teachers in Iran. They employed two tools to collect the needed data for the study included interviews based on GT procedures and a questionnaire of (64) items spreads over four domains, where applied on a sample of (20), (130) high school teacher respectively. The finding of the study gave emphasis to the existence of professional challenges; it showed the educational factor came to be in the first level compared to the social factor that took the lowest level. This implies that the educational factor has a significant effect on the level of satisfaction of EFL teacher. As for years of experience and gender, they did not show an important impact on teachers' perspectives toward professional challenges.

\section{Methodology}

\subsection{Participants}

The study sample included (34) English teachers hold different academic degrees (Bachelor and Master) with an age ranged from 24 to 60 years. They were chosen randomly from different public secondary schools at Al-Karakh side of Baghdad city to identify the difficulties that they face over their teaching process of English language. The participants were (8) males and (26) females teachers for the first three grades of secondary schools.

Table 1. Sample distribution according to the gender and academic education

\begin{tabular}{llll}
\hline Gender & \multicolumn{3}{l}{ Academic Education } \\
\hline Male & $\mathbf{8}$ & Bachelor & 33 \\
Female & 26 & Master & 1 \\
Total & 34 & Total & 34 \\
\hline
\end{tabular}




\subsection{Instrument}

The study is quantitative in nature in which the needed data is basically collected based on a questionnaire a adopted by Ahmad, (2004) which consists of (61) items distributed over nine domains. The questionnaire is a 5-Likert scale ranges from strongly agree to strongly disagree designed to determine the difficulties that English teachers encounter through the process of teaching English as a foreign language. To ensure its validity, the questionnaire was exposed to a group of experts specialized in educational and social sciences. A number of items were eliminated to suit the intended purpose in which the new version of the questionnaire confined to (37) items distributed over six domains namely (Difficulties in developing profession, difficulties related to equipment and facilities, difficulties with colleagues, difficulties with students, difficulties in educational supervision, and difficulties in school textbook). As for reliability, a Cronbach alpha was run to test the internal consistency of the questionnaire, which found to be (0.71) within the range of the accepted value 0.70 to 0.95 (Tavakol \& Dennick, 2011).

Table 2. Mean, standard deviation, and percentage of all items

\begin{tabular}{|c|c|c|c|c|}
\hline No & Item & $\mathbf{M}$ & Std. I & \%age \\
\hline 1 & $\begin{array}{l}\text { Professional development opportunities offered by ministry of } \\
\text { education are insufficient. }\end{array}$ & 3.82 & 1.06 & 76.40 \\
\hline 2 & In-service training courses organized by ministry of education are insufficient. & 3.56 & 0.99 & 71.20 \\
\hline 3 & Opportunities to keep abreast of development in English teaching are nonexistent. & 3.82 & 1.17 & 76.40 \\
\hline 4 & $\begin{array}{l}\text { I have never gotten an opportunity to continue my graduate study due } \\
\text { to the strict regulations. }\end{array}$ & 3.18 & 1.06 & 63.60 \\
\hline 5 & Opportunities to participate in specialized courses are not available. & 3.35 & 1.10 & 67.00 \\
\hline 6 & English language audio-visual aids and equipment are in short supply. & 3.79 & 1.12 & 75.80 \\
\hline 7 & The available equipment is not sufficient for large numbers of students. & 4.21 & 0.64 & 84.20 \\
\hline 8 & School library has a shortage of English language references. & 4.32 & 0.88 & 86.40 \\
\hline 9 & The available resources do not support English teachers in applying school textbook objectives. & 3.91 & 1.24 & 78.20 \\
\hline 10 & There is no coordination between my colleagues and me. & 2.88 & 1.01 & 57.60 \\
\hline 11 & There is a negative attitude of teachers (of other disciplines) towards English Language. & 2.85 & 1.13 & 57.00 \\
\hline 12 & My colleagues at school do not appreciate my efforts. & 2.38 & 0.95 & 47.60 \\
\hline 13 & My colleagues do not motivate first-rate students in English. & 2.82 & 1.14 & 65.40 \\
\hline 14 & My colleagues mock of all my activities related to English language. & 3.06 & 1.13 & 61.20 \\
\hline 15 & Many students fail to bring their English textbooks to class. & 2.88 & 1.09 & 57.60 \\
\hline 16 & Students generally do not receive English well. & 3.74 & 0.96 & 74.80 \\
\hline 17 & Lack of incentives for students make them uninterested in English. & 4.12 & 0.77 & 82.40 \\
\hline 18 & The low grades in English make students more interested in other disciplines. & 3.82 & 0.67 & 76.40 \\
\hline 19 & Limited interest in English only by a small number of students makes others lose spirit of perseverance. & 3.79 & 0.81 & 75.80 \\
\hline 20 & The majority of students abstain from class participation for fear of making mistakes. & 3.88 & 0.91 & 77.60 \\
\hline 21 & The lack of interest in developing the abilities of slow learners to understand the material. & 3.91 & 0.79 & 78.20 \\
\hline 22 & Classes are overcrowded. & 4.29 & 0.84 & 85.80 \\
\hline 23 & Educational supervisor often concentrates on abrupt visits in his/her evaluation of teacher's performance. & 3.68 & 0.84 & 73.60 \\
\hline 24 & Educational supervisor does not encourage the use of modern methods Of teaching. & 2.62 & 1.26 & 52.40 \\
\hline
\end{tabular}




\begin{tabular}{|c|c|c|c|c|}
\hline 25 & Educational supervisor does not consider the school's physical resources available for teacher evaluation. & 3.32 & 0.95 & 66.40 \\
\hline 26 & $\begin{array}{l}\text { The educational supervisor often evaluates the English teacher based on class observed and ignores } \\
\text { other aspects of evaluation. }\end{array}$ & 3.44 & 1.13 & 68.80 \\
\hline 27 & Supervision visits are not enough. & 3.62 & 0.99 & 72.40 \\
\hline 28 & $\begin{array}{l}\text { Educational supervisor does not contribute to finding solution for professional problems facing } \\
\text { English_language teachers. }\end{array}$ & 3.50 & 1.19 & 70.00 \\
\hline 29 & $\begin{array}{l}\text { Educational supervisor does not respect teachers' opinions and suggestions. Rather, he imposes his own } \\
\text { on them. }\end{array}$ & 3.12 & 1.30 & 62.40 \\
\hline 30 & Educational supervisor's qualification does not qualify him to work as a supervisor. & 3.85 & 0.89 & 77.00 \\
\hline 31 & $\begin{array}{l}\text { English language teachers' suggestions are not taken into consideration when introducing changes } \\
\text { on the school textbook. }\end{array}$ & 3.82 & 1.06 & 76.40 \\
\hline 32 & $\begin{array}{l}\text { The school textbook often restricts English teachers and does not allow a teacher for choice } \\
\text { according to school reality. }\end{array}$ & 3.59 & 1.02 & 71.80 \\
\hline 33 & The school textbook largely concentrates on theoretical side other than practical side. & 2.91 & 1.11 & 58.20 \\
\hline 34 & The school textbook is not in harmony with the Iraqi society's traditions and customs. & 3.38 & 1.05 & 67.60 \\
\hline 35 & $\begin{array}{l}\text { The amount of vocabularies in the school textbook does not match the number of classes allocated for } \\
\text { English. }\end{array}$ & 3.59 & 0.86 & 71.80 \\
\hline 36 & The school textbook does not have clear criteria to give English language grades. & 3.85 & 0.89 & 77.00 \\
\hline 37 & The school textbook does not often take into consideration individual differences among_students. & 3.50 & 0.99 & 72.40 \\
\hline
\end{tabular}

\subsection{Data Analysis}

The researcher employed a descriptive statistics analysis to identify the most influential domain by estimating the frequency of each selected choice: (SD-1), (D-2), (N-3), (A-4), (SA-5). As for question two, Pearson's Chi-Square test was used to determine the significant difference between male and female teachers regarding their perspective toward the difficulties in teaching English.

\section{Results}

The study attempts to answer two main questions:

1- What are the most influential difficulties encountering Iraqi-English teachers as seen by the teachers themselves?

Table 3. Means and Standard deviations of the six difficulty domains

\begin{tabular}{llll}
\hline & Difficulty Domain & Std. Dev. & Mean \\
\hline B. & Equipment and Facilities scarcity & 0.97 & 4.057 \\
D. & Difficulties with Students & 0.855 & 3.803 \\
F. & Difficulties in School Text book & 0.982 & 3.57 \\
A. & Developing teacher profession & 1.076 & 3.546 \\
E. & Difficulties in Educational Supervision & 0.957 & 3.335 \\
C. & Difficulties with Colleagues & 1.072 & 2.798 \\
\hline
\end{tabular}




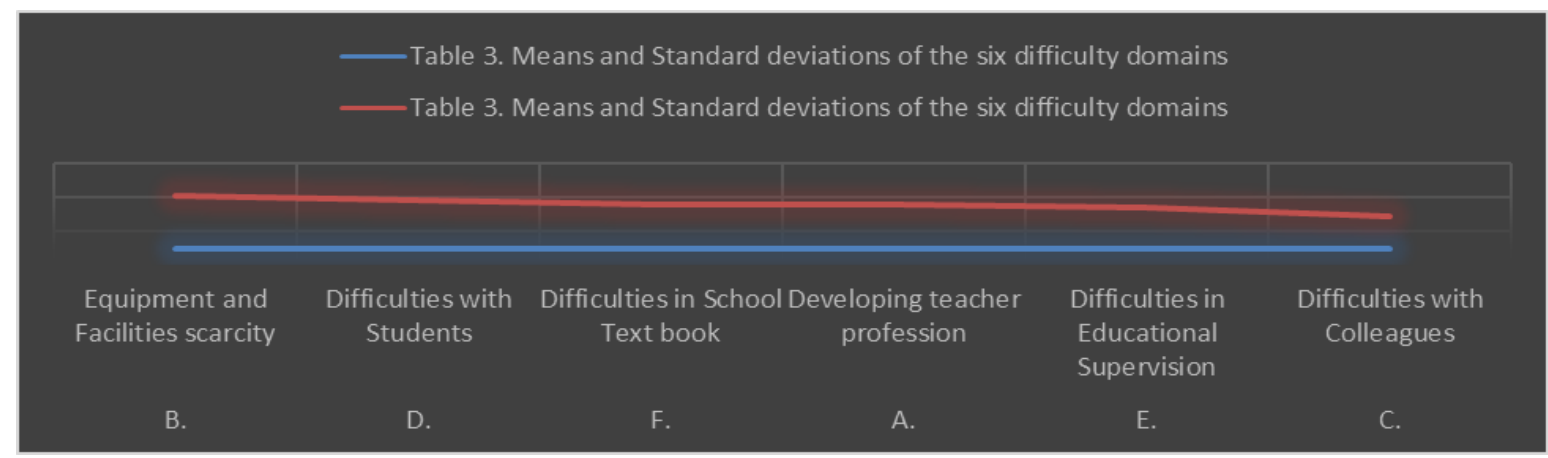

As shown in table (2), the scarcity of equipment and facilities has taken the lead comparing to the difficulties with Colleagues, which came at the end in term of difficulties that experienced by English teachers. This implies the lack of materials is a predominant problem that majority of public secondary school have. It has a significant influence on teaching and learning process, due to this problem, the capability of imparting information and receiving this information by students will greatly be effected, because the availability of teaching-learning aids encourage and enhance students productivity.

\section{Does the variable of gender has a significant influence on teacher's perspectives toward teaching difficulties?}

Table 4-1. Pearson Chi-Square regards to gender

\begin{tabular}{|c|c|c|c|c|}
\hline \multirow{2}{*}{\multicolumn{2}{|c|}{ A. Difficulties in developing profession }} & \multicolumn{3}{|c|}{ Pearson Chi-Square } \\
\hline & & Value & df & $\begin{array}{l}\text { Asymptotic } \\
\text { Sig (2-sides) }\end{array}$ \\
\hline 1 & Professional development opportunities offered by Ministry of Education are insufficient. & 3.433 & 4 & .488 \\
\hline 2 & In-service training courses organized by the Ministry of Education are insufficient. & .657 & 3 & .883 \\
\hline 3 & $\begin{array}{l}\text { Opportunities to keep abreast with the development in English language teaching are } \\
\text { nonexistent. }\end{array}$ & 2.700 & 4 & 609 \\
\hline 4 & I have never got an opportunity to pursue my graduate study, due to strict regulations. & 2.367 & 4 & 669 \\
\hline 5 & Opportunities to participate in specialized courses are not available. & 13.631 & 4 & .009 \\
\hline
\end{tabular}

Table 4-2. Pearson Chi-Square regards to gender

\begin{tabular}{|c|c|c|c|c|}
\hline \multirow{2}{*}{\multicolumn{2}{|c|}{ B. Equipment and Facility-Related Difficulties }} & \multicolumn{3}{|c|}{ Pearson Chi-Square } \\
\hline & & \multirow{2}{*}{\begin{tabular}{|l|} 
Value \\
8.218 \\
\end{tabular}} & \multirow{2}{*}{\begin{tabular}{|l|}
$d f$ \\
4
\end{tabular}} & \multirow{2}{*}{\begin{tabular}{|c|} 
Asymptotic \\
Sig (2-sides) \\
.084
\end{tabular}} \\
\hline 1 & English language audio-visual aids and equipment are in short supply. & & & \\
\hline 2 & The available equipment is not sufficient for large numbers of students. & .155 & 2 & .925 \\
\hline 3 & School library has a shortage of English language references. & .195 & 2 & .907 \\
\hline 4 & The available resources do not support English teachers in applying school textbook objectives. & 3.680 & 4 & .451 \\
\hline
\end{tabular}


Table 4-3. Pearson Chi-Square regards to gender

\begin{tabular}{|l|l|l|l|l|}
\hline \multicolumn{2}{|l|}{ C. Difficulties with Colleagues } & \multicolumn{2}{l|}{ Pearson Chi-Square } \\
\cline { 3 - 5 } \cline { 3 - 5 } & Value & $\begin{array}{l}\text { df } \\
\text { Asymptotic } \\
\text { Sig (2-sides) }\end{array}$ & & .114 \\
\hline 1 & There is no coordination between my colleagues and me. & 12.401 & 4 & .015 \\
\hline 2 & There is a negative attitude of teachers (of other disciplines) towards English Language. & 1.426 & 4 & .840 \\
\hline 3 & My colleagues at school do not appreciate my efforts. & 2.798 & 3 & .424 \\
\hline 5 & My colleagues do not motivate first-rate students in English. & 2.930 & 4 & .570 \\
\hline
\end{tabular}

Table 4-4 Pearson Chi-Square regards to gender

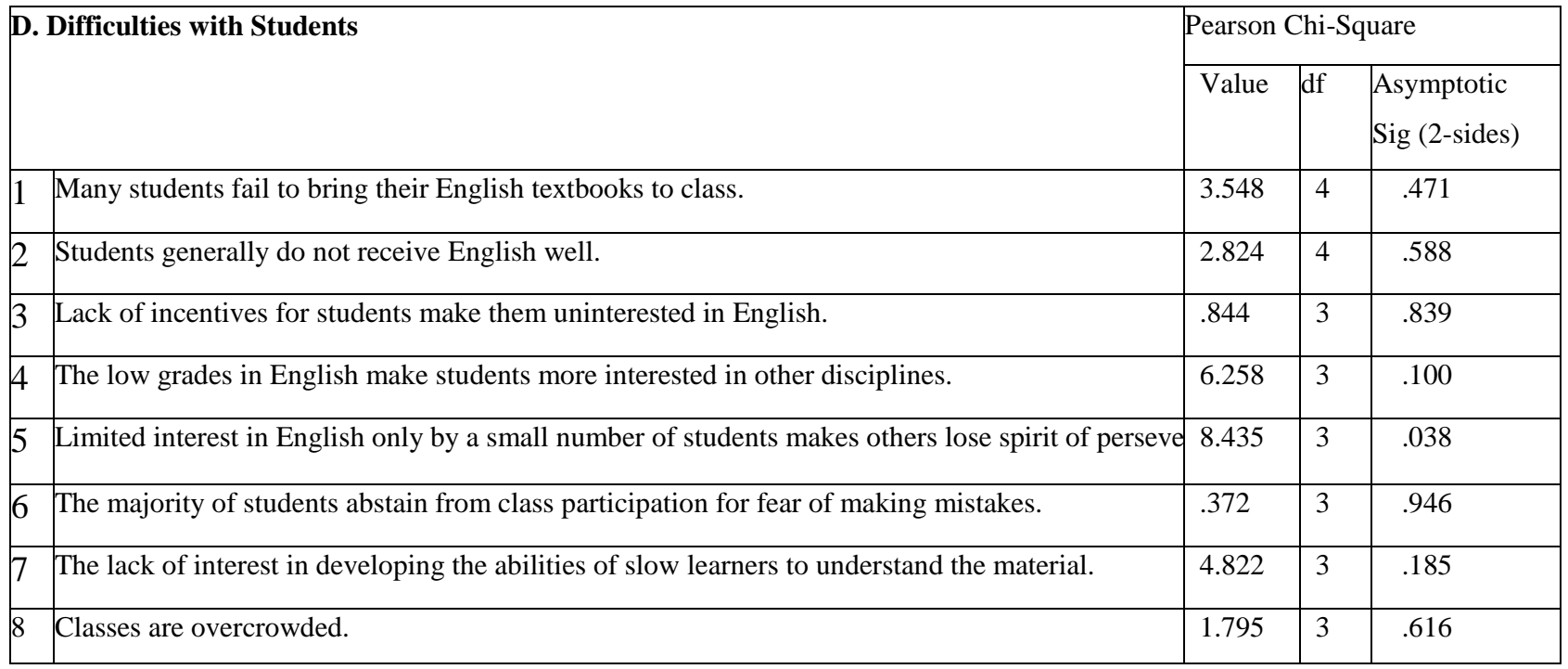

Table 4-5. Pearson Chi-Square regards to gender

\begin{tabular}{|c|c|c|c|c|}
\hline \multicolumn{2}{|r|}{ E. Difficulties in Educational Supervision } & \multicolumn{3}{|c|}{ Pearson Chi-Square } \\
\hline & & \multirow{3}{*}{\multicolumn{2}{|c|}{\begin{tabular}{|l|l|} 
Value & $\mathrm{df}$ \\
2.952
\end{tabular}}} & \multirow{3}{*}{ 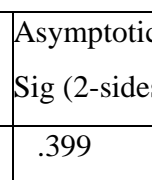 } \\
\hline & & & & \\
\hline 1 & Educational supervisor often concentrates on abrupt visits in his/her evaluation of teacher's performance. & & & \\
\hline 2 & Educational supervisor does not encourage the use of modern methods Of teaching. & 6.335 & 4 & .175 \\
\hline 3 & $\begin{array}{l}\text { Educational supervisor does not consider the school's physical resources available for teacher } \\
\text { evaluation. }\end{array}$ & 3.322 & 3 & .345 \\
\hline 4 & $\begin{array}{l}\text { The educational supervisor often evaluates the English teacher based on class observed and ignores } \\
\text { other aspects of evaluation. }\end{array}$ & 15.801 & 4 & .003 \\
\hline 5 & Supervision visits are not enough. & 8.446 & 4 & .077 \\
\hline 6 & $\begin{array}{l}\text { Educational supervisor does not contribute to finding solution for professional problems } \\
\text { facing_English_language teachers. }\end{array}$ & 4.266 & 4 & .371 \\
\hline 7 & $\begin{array}{l}\text { Educational supervisor does not respect teachers' opinions and suggestions. Rather, he imposes his } \\
\text { own on them. }\end{array}$ & 14.945 & 4 & .005 \\
\hline 8 & Educational supervisor's qualification does not qualify him to work as a supervisor. & 4.151 & 4 & .386 \\
\hline
\end{tabular}


Table 4-6. Pearson Chi-Square regards to gender

\begin{tabular}{|c|c|c|c|c|}
\hline \multirow{2}{*}{\multicolumn{2}{|c|}{ F. Difficulties in School Text book }} & \multicolumn{3}{|c|}{ Pearson Chi-Square } \\
\hline & & \multirow{2}{*}{\begin{tabular}{|l|} 
Value \\
3.036 \\
\end{tabular}} & \multirow{2}{*}{$\begin{array}{l}\mathrm{df} \\
4\end{array}$} & \multirow{2}{*}{\begin{tabular}{|l} 
Asymptotic \\
Sig (2-sides) \\
.562
\end{tabular}} \\
\hline 1 & $\begin{array}{l}\text { English language teachers' suggestions are not taken into consideration when introducing } \\
\text { changes on the school textbook. }\end{array}$ & & & \\
\hline 2 & $\begin{array}{l}\text { The school textbook often restricts English teachers and does not allow a teacher for choice } \\
\text { according to school reality. }\end{array}$ & .345 & 4 & .987 \\
\hline 3 & The school textbook largely concentrates on theoretical side other than practical side. & 5.219 & 4 & .266 \\
\hline 4 & The school textbook is not in harmony with the Iraqi society's traditions and customs. & 1.491 & 4 & .828 \\
\hline 5 & $\begin{array}{l}\text { The amount of vocabularies in the school textbook does not match the number of classes } \\
\text { allocated for English. }\end{array}$ & 5.285 & 4 & .259 \\
\hline 6 & The school textbook does not have clear criteria to give English language grades. & 4.821 & 3 & .185 \\
\hline 7 & $\begin{array}{l}\text { The school textbook does not often take into consideration individual differences } \\
\text { among_students. }\end{array}$ & 2.639 & 4 & .620 \\
\hline
\end{tabular}

Generally, the results of Pearson Chi-Square as shown in tables (4-1, 4-2, 4-3, 4-4, 4-5, 4-6) revealed that there is no statistically significant difference between male and female teachers at the level $(a=0.05)$ in their perspective toward the difficulties in teaching English. Accordingly, the null hypothesis is accepted. However, Male and female teachers have displayed a significant difference at a number of difficulties in favor of male as cleared in Item (5) within the difficulties in developing profession, item (2) within the difficulties with Colleagues, and items $(4,7)$ within the difficulties in Educational Supervision.

\section{Discussion}

Since teaching English has become one of the priorities for the government, it is necessary to identify the most influential difficulty domains in teaching the English language. Thus, the main objective of the current research is to determine the most influential difficulties that face Iraqi-English teachers as they have experienced through the teaching process. Two questions were raised; the finding of the first question came to be congruent with the findings of studies conducted by (Mahmoud, 2004; Evue, 2013, Herzallah, 2011; Razmjoo \& Mavaddat, 2016) revealed that the scarcity of materials and facilities constitute the highest influential domain compared to the other domains that come in turn. According to these studies, which were conducted in different contexts of the Middle East, it is clear that teaching materials form a significant obstacle for English teachers not only in Iraq but also in many other places.

Thus, it is incumbent upon the government to find feasible solutions to overcome these difficulties. As for the second question, which seeks to the effect of teachers' gender on their perspective toward teaching difficulties. The finding is in line with studies' results of (Razmjoo \& Mavaddat, 2016; Mahmoud, 2004) disclosed that both male and female teachers experience approximately the same level of difficulties in teaching English language, which means there is no statistically significant difference between male and female teachers' perspectives toward teaching English difficulties.

\section{Conclusion and Recommendations}

The study attempted to determine the most influential difficulties that face Iraqi-English teachers from their perspectives and the extent to which the variable of gender could influence teachers' point of view toward the difficulties of teaching. Based on the research questions, the study reached that the scarcity of equipment and facilities has taken the lead followed by difficulties with Students comparing to the difficulties with Colleagues that took the last stage. Additionally, teachers' gender did not show a significant difference at the level $(\mathrm{a}=0.05)$ in their perspective toward the difficulties in teaching English. 
Based on the percentages of each item in the six domains, English teachers are facing real problems through the teaching process even if some items showed medium percentages, but they are still effective need to be managed. In regard of recommendations, Teachers must be provided with in-service training courses to enhance their knowledge and keep them breast with latest developments in teaching field as well as Teachers must be provided with what they need in term of teaching aids that assist in imparting information easily to the learners. Additionally, Teachers and parents must have a sort of collaboration to ensure that students are serious in achieving their tasks.

\section{References}

Acker S. (1999). The Realities of Teachers' Work: never a dull moment. London: Cassell.

Agnew, D. (1999). “An Evaluation of the Getz-Roanoke country School Division’s School counselor per Group clinical supervision program”. Dissertation Abstract International AAC9905151.

Ahmad, M. S. M. (2004). Professional Difficulties Facing Secondary School English Language Teachers and It's Effect in Classroom Performance in Northern Governorates of Palestine (Doctoral dissertation).

Archana, S., \& Usha Rani, K. (2017). Role of a teacher in English language teaching (ELT). International Journal of Educational Science and Research (IJESR), 7(1), 1-4.

Brown, H. (2014). Principles of language learning and teaching, 6th Edition, USA: Pearson Education, Inc.

Brown, H. D. (2007). Principles of language learning and teaching (5th ed.). New York: Pearson Education.

Crystal, David. English as a Global Language. 2nd ed. Cambridge: Cambridge UP, 2003.

Evue, A. (2013). Challenges facing the teaching of English language in secondary schools in Aniocha south local government area of Delta state Nigeria. African Education Indices, 5(1), $1-11$.

Hamadat, M (2009). Education system and teaching methods, Amman, Dar Al-Hamed.

Harmer, Jeremy, The practice of English language teaching, London, Longman, 4th edition, 2007, p. 57.

Herzallah, A. A. (2011). Professional Development Obstacles Facing Primary English Language Teachers in Northern Gaza. Professional Development Obstacles Facing Primary English Language Teachers in Northern Gaza.

Horne. B 2004. 'culture and the language classroom challenge expectations of culture behavior.' Bulleting of the faculty of education, chiba university 52:87-92.

Khankar, Q. Ismail (2001) Identify the most important problems of language curriculum English for the first grade secondary school from the viewpoint of the parameters province Taif. Master. College of Education. Umm Al Qura University. 
Lee, J. F., \& Van Patten, B. (2003). Making communicative language teaching happen (2nd ed.). New York: McGraw-H.

Ormstor, M, et al. (1995). "Inspection and Change: Help or Hindrance for the Classroom Teacher,” British Journal of In-Service Education. 21.3 (PP.35-39).

Ornstein, A. C. \& Hunkins, F. P. (1998). Curriculum, Foundations, Principlesand Issues. Allyn\& Bacon: US.

Pakir, A. (1999). Connecting English in the context of internationalization. TESOL Quarterly, $33(1)$.

Razmjoo, S. A., \& Mavaddat, R. (2016). Understanding Professional Challenges Faced by Iranian Teachers of English. International Journal of English Linguistics, 6(3).

Saeed, N. R. (2015). Problems of Teaching English in Iraqi Public Schools in Mosul for the Intermediate Stage from the Teachers' Point of View (Doctoral dissertation, Middle East University).

Sakai, H., \& Kikuchi, K. (2009). An analysis of demotivators in the EFL classroom. System, 37, 57-69. http://dx.doi.org/10.1016/j.system.2008.09.005 .

Sue, B., The 7 Roles of a Teacher in the 21 st Century, 2013, retrieved from https://www.etoninstitute.com/blog/item/26-the-7-roles-of-a-teacher-in-the-21st-century.

Tavakol, M., \& Dennick, R. (2011). Making sense of Cronbach's alpha. International journal of medical education, $2,53$.

Toolan, M. (2009) (ed.). Language teaching: Integrational linguistic approaches. New York: Routledge.

Van Veen, K., Zwart, R., \& Meirink, J. (2012). What makes teacher professional development effective? A literature review. In Teacher learning that matters (pp. 23-41). Routledge.

Wang, M. C., \& Haertel, G. D. (2017). Teacher relationships. A digest of research from the Laboratory for Student Success.

Zeichner, K. \& Noffke, S. (2001) Practitioner Research, in Richardsson (Ed). Handbook of Research on Teaching, 4th edn. Washington DC: AERA.

\section{Copyrights}

Copyright for this article is retained by the author(s), with first publication rights granted to the journal. This is an open-access article distributed under the terms and conditions of the Creative Commons Attribution license (http://creativecommons.org/licenses/by/4.0/). 